\title{
Unprecedented Ambient Sulfur Trioxide (SO3) Detection : Possible Formation Mechanism and Atmospheric Implications
}

\author{
Yao, Lei \\ 2020-11-10
}

Yao , L , Fan , X, Yan , C , Kurten , T, Dällenbach , K, Li , C , Wang , Y, Guo , Y, Dada , L , Rissanen, M P , Cai , J , Tham , Y J , Zha, Q, Zhang, S , Du , W , Yu , M , Zheng , F , Zhou , Y, Kontkanen, J , Chan , T , Shen , J , Kujansuu , J T , Kangasluoma , J , Jiang , J , Wang , L, Worsnop , D R, Petäjä , T, Kerminen, V-M , Liu , Y, Chu , B , He , H, Kulmala , M \& Bianchi , F 2020 , ' Unprecedented Ambient Sulfur Trioxide (SO3) Detection : Possible Formation Mechanism and Atmospheric Implications ' , Environmental Science \& Technology Letters, vol. 7 , no. 11 , pp. 809-818 . https://doi.org/10.1021/acs.estlett.0c00615

http://hdl.handle.net/10138/324254

https://doi.org/10.1021/acs.estlett.0c00615

cc_by

publishedVersion

Downloaded from Helda, University of Helsinki institutional repository.

This is an electronic reprint of the original article.

This reprint may differ from the original in pagination and typographic detail.

Please cite the original version. 


\section{Unprecedented Ambient Sulfur Trioxide $\left(\mathrm{SO}_{3}\right)$ Detection: Possible Formation Mechanism and Atmospheric Implications}

Lei Yao, Xiaolong Fan, Chao Yan, Theo Kurtén, Kaspar R. Daellenbach, Chang Li, Yonghong Wang, Yishuo Guo, Lubna Dada, Matti P. Rissanen, Jing Cai, Yee Jun Tham, Qiaozhi Zha, Shaojun Zhang, Wei Du, Miao Yu, Feixue Zheng, Ying Zhou, Jenni Kontkanen, Tommy Chan, Jiali Shen, Joni T. Kujansuu, Juha Kangasluoma, Jingkun Jiang, Lin Wang, Douglas R. Worsnop, Tuukka Petäjä, Veli-Matti Kerminen, Yongchun Liu, Biwu Chu, Hong He,* Markku Kulmala,* and Federico Bianchi*

ABSTRACT: Sulfur trioxide $\left(\mathrm{SO}_{3}\right)$ is a crucial compound for atmospheric sulfuric acid $\left(\mathrm{H}_{2} \mathrm{SO}_{4}\right)$ formation, acid rain formation, and other atmospheric physicochemical processes. During the daytime, $\mathrm{SO}_{3}$ is mainly produced from the photo-oxidation of $\mathrm{SO}_{2}$ by $\mathrm{OH}$ radicals. However, the sources of $\mathrm{SO}_{3}$ during the early morning and night, when $\mathrm{OH}$ radicals are scarce, are not fully understood. We report results from two field measurements in urban Beijing during winter and summer 2019, using a nitrateCI-APi-LTOF (chemical ionization-atmospheric pressure interface-long-time-offlight) mass spectrometer to detect atmospheric $\mathrm{SO}_{3}$ and $\mathrm{H}_{2} \mathrm{SO}_{4}$. Our results show the level of $\mathrm{SO}_{3}$ was higher during the winter than during the summer, with high $\mathrm{SO}_{3}$ levels observed especially during the early morning $(\sim 05: 00$ to $\sim 08: 30)$ and night $\left(\sim 18: 00\right.$ to $\sim 05: 00$ the next day). On the basis of analysis of $\mathrm{SO}_{2}, \mathrm{NO}_{x}$, black carbon, traffic flow, and atmospheric ions, we suggest $\mathrm{SO}_{3}$ could be formed from the catalytic oxidation of $\mathrm{SO}_{2}$ on the surface of traffic-related black carbon. This previously

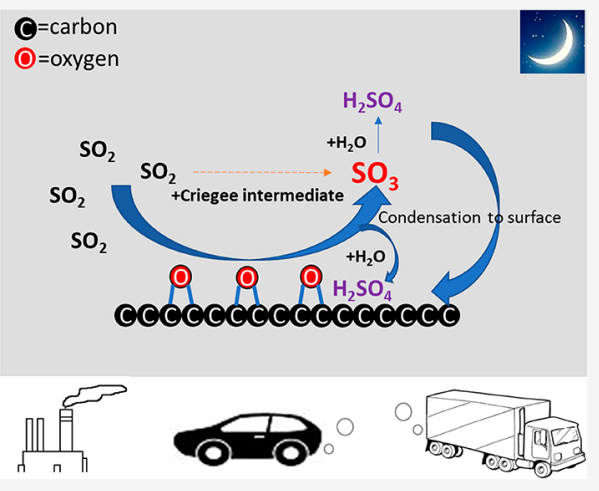
unidentified $\mathrm{SO}_{3}$ source results in significant $\mathrm{H}_{2} \mathrm{SO}_{4}$ formation in the early morning and thus promotes sub- $2.5 \mathrm{~nm}$ particle formation. These findings will help in understanding urban $\mathrm{SO}_{3}$ and formulating policies to mitigate secondary particle formation in Chinese megacities.

\section{INTRODUCTION}

Atmospheric $\mathrm{SO}_{3}$ is a vital intermediate in gaseous $\mathrm{H}_{2} \mathrm{SO}_{4}$ formation, which in turn is a crucial compound in acid rain formation, new particle formation, secondary aerosol formation, and other atmospheric physicochemical processes. $^{1-8}$ During the daytime, when the intensity of UVB (ultraviolet radiation $\mathrm{B}$ ) radiation that leads to the formation of $\mathrm{OH}$ radicals is high, $\mathrm{SO}_{3}$ is mainly formed by atmospheric photo-oxidation of $\mathrm{SO}_{2}$ by $\mathrm{OH}$ radicals. The mechanism of formation of $\mathrm{SO}_{3}$ from photo-oxidation can be written as

$$
\begin{aligned}
& \mathrm{SO}_{2}+\mathrm{OH}+\mathrm{M} \rightarrow \mathrm{HOSO}_{2}+\mathrm{M} \\
& \mathrm{HOSO}_{2}+\mathrm{O}_{2} \rightarrow \mathrm{SO}_{3}+\mathrm{HO}_{2}
\end{aligned}
$$

However, during the early morning and at night, when $\mathrm{OH}$ radicals are scarce, the sources of atmospheric $\mathrm{SO}_{3}$ remain unclear. Stabilized Criegee intermediates ( $\mathrm{sCI}$; general formula of $R_{1} R_{2} C O O$ ) generated from the ozonolysis of alkenes have been found to be an important gas-phase oxidant for $\mathrm{SO}_{2}$ in addition to $\mathrm{OH}$ (eq R3): ${ }^{9,10}$

$$
\mathrm{R}_{1} \mathrm{R}_{2} \mathrm{COO}+\mathrm{SO}_{2} \rightarrow \mathrm{R}_{1} \mathrm{R}_{2} \mathrm{C}=\mathrm{O}+\mathrm{SO}_{3}
$$

Besides gas-phase oxidation of $\mathrm{SO}_{2}$ by $\mathrm{OH}$ radicals and $\mathrm{sCI}, \mathrm{SO}_{3}$ may also be formed from the heterogeneous oxidation of $\mathrm{SO}_{2}$ on oxygen-functionalized graphene and soot surfaces. ${ }^{11-13} \mathrm{He}$ et al. have proposed that $\mathrm{SO}_{2}$ molecules can react with surface epoxide groups of carbonaceous (or soot) aerosols, leading to $\mathrm{SO}_{3}$ formation. These surface epoxy groups are considerably enhanced by atmospheric aging of soot particles in the presence of $\mathrm{O}_{2} \cdot{ }^{12,14}$ Additionally, a recent theoretical study revealed high atmospheric water content could promote the oxidation of $\mathrm{SO}_{2}$ to $\mathrm{SO}_{3}$ by $\mathrm{O}_{2}$ on carbonaceous aerosol surfaces. ${ }^{15}$ Although extensive laboratory studies have reported that persistent particulate $\mathrm{H}_{2} \mathrm{SO}_{4}$ and sulfate can be formed from catalytic heterogeneous reaction between $\mathrm{SO}_{2}$ and carbon (soot) particles in the presence of $\mathrm{O}_{2}, \mathrm{O}_{3}, \mathrm{NO}_{x}, \mathrm{NH}_{3}$, and water, ${ }^{16-19}$ the

Received: August 7, 2020

Revised: September 24, 2020

Accepted: September 25, 2020

Published: September 25, 2020

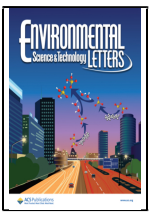



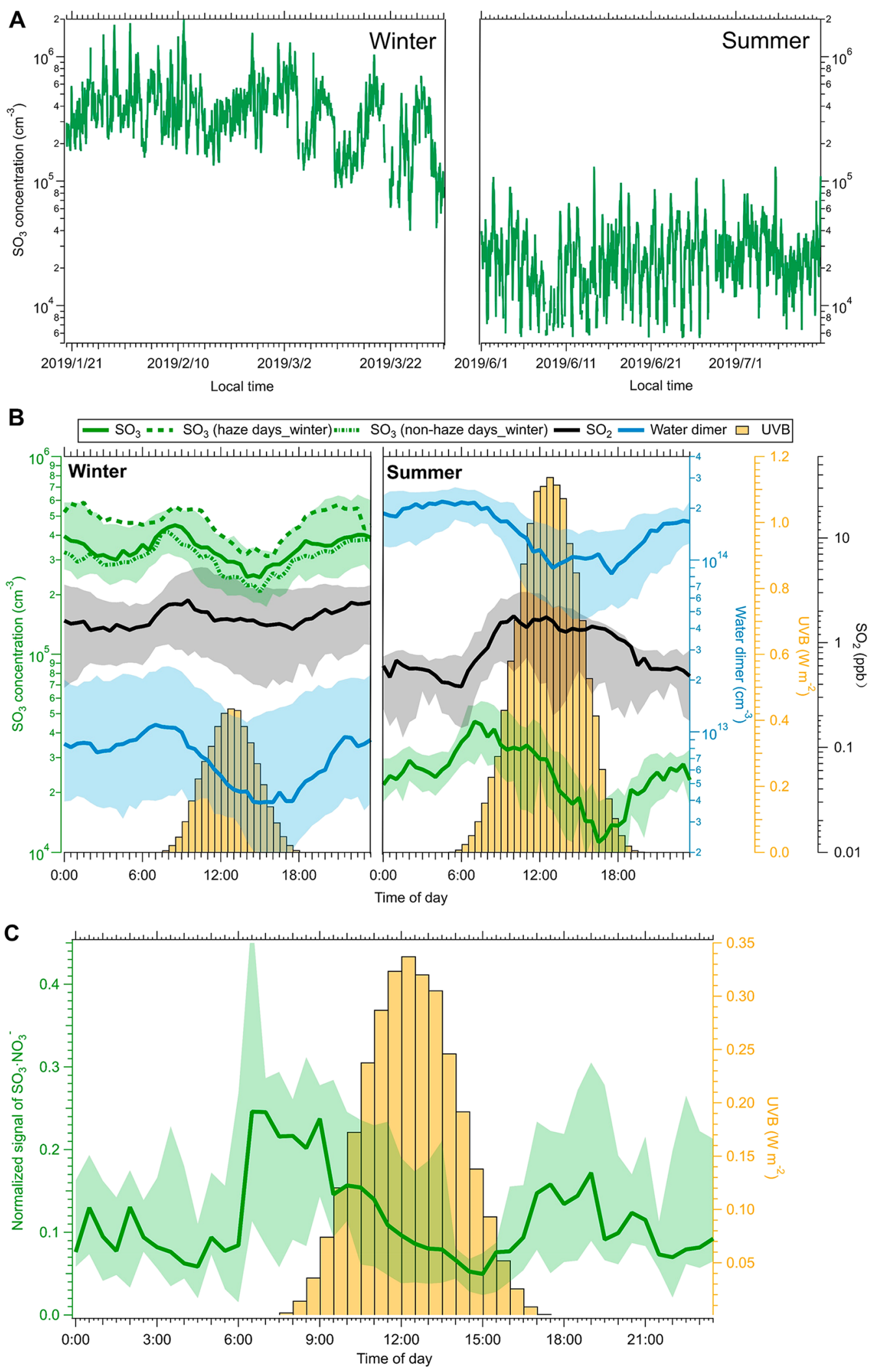

Figure 1. (A) Time series of $\mathrm{SO}_{3}$ during the winter (January 20 to March 31, 2019) and summer (June 1 to July 10, 2019), (B) median diurnal patterns of $\mathrm{SO}_{3}, \mathrm{UVB}$, and atmospheric water dimer concentrations during the winter and summer, and (C) median normalized intensities of the atmospheric ion $\mathrm{SO}_{3} \cdot \mathrm{NO}_{3}{ }^{-}$. Rainy and snowy days were excluded. The shadows show the values from the 25 th to 75 th percentile. In panel $\mathrm{B}$, the dashed lines show diurnal variations of $\mathrm{SO}_{3}$ during haze and nonhaze days. The water dimer concentration was calculated on the basis of temperature and relative humidity. ${ }^{26,39}$ In panel $\mathrm{C}$, the signals of atmospheric ion $\mathrm{SO}_{3} \cdot \mathrm{NO}_{3}{ }^{-}$were normalized by the sum of $\mathrm{NO}_{3}{ }^{-}$and $\mathrm{HNO}_{3}$. $\mathrm{NO}_{3}^{-}$that are dominant natural charged ions in urban Beijing (Figure S7). 
intermediate precursors of particulate sulfate, and the molecular-level details of this process, remain unclear. In addition to atmospheric formation of $\mathrm{SO}_{3}$ via the oxidation of $\mathrm{SO}_{2}$, a large amount of $\mathrm{SO}_{3}$ can also be emitted to the air from coal-fired power plants and other industrial processes related to coal combustion and then be rapidly converted to $\mathrm{H}_{2} \mathrm{SO}_{4}{ }^{20-22}$

In the atmosphere, the water-catalyzed hydration of $\mathrm{SO}_{3}$ plays an essential role in $\mathrm{H}_{2} \mathrm{SO}_{4}$ formation (eq R4).

$$
\mathrm{SO}_{3}+2 \mathrm{H}_{2} \mathrm{O}+\mathrm{M} \rightarrow \mathrm{H}_{2} \mathrm{SO}_{4}+\mathrm{H}_{2} \mathrm{O}+\mathrm{M}
$$

In reaction $\mathrm{R} 4$, the second water molecule acts as a catalyst and significantly reduces the energy barrier of $\mathrm{SO}_{3}$ hydration. ${ }^{23,24}$ The rate coefficient of the reaction of $\mathrm{SO}_{3}$ with the water dimer $\left[\left(\mathrm{H}_{2} \mathrm{O}\right)_{2}\right]$, or $\mathrm{H}_{2} \mathrm{O}$-catalyzed hydrolysis, is between $10^{-12}$ and $10^{-10} \mathrm{~cm}^{3}$ molecule $\mathrm{s}^{-1}$, resulting in a very short lifetime $(<1 \mathrm{~s})$ of $\mathrm{SO}_{3} \cdot{ }^{23-26}$ In the atmosphere, besides water-catalyzed hydration, ammonia, sulfuric acid, formic acid, nitric acid, and oxalic acid (among others) can also act as catalysts for the $\mathrm{SO}_{3}$ hydration process and thus facilitate $\mathrm{H}_{2} \mathrm{SO}_{4}$ formation. ${ }^{25,27-29}$

The detection of $\mathrm{SO}_{3}$ is challenging owing to its high reactivity with water in ambient air. Various measurement technologies have been utilized for $\mathrm{SO}_{3}$ detection in flue gases, including the controlled condensation method, absorption by isopropyl alcohol, selective reaction method with calcium oxalate, and spectroscopy and mass spectrometry methods. $^{22,30}$ The detection limits of these methods are unfortunately too high to measure trace-level $\mathrm{SO}_{3}$ in ambient air. In some laboratory studies, the ions $\mathrm{SiF}_{5}^{-}, \mathrm{SF}_{6}^{-}, \mathrm{NO}_{3}{ }^{-}$. $\mathrm{HNO}_{3}$, and $n-\mathrm{C}_{3} \mathrm{H}_{7} \mathrm{NH}_{3}{ }^{+}$have been used as reagent ions to detect $\mathrm{SO}_{3}{ }^{31-35}$

In this study, we deployed a nitrate-chemical ionizationatmospheric pressure interface-long-time-of-flight (nitrate-CIAPi-LTOF) mass spectrometer in two field measurements for atmospheric $\mathrm{SO}_{3}$ and $\mathrm{H}_{2} \mathrm{SO}_{4}$ during the winter from January 20 to March 31 and during the summer from June 1 to July 10, 2019, in urban Beijing. This paper presents, for the first time, the trace-level measurement of gaseous $\mathrm{SO}_{3}$ by a nitrate-CI-APi-LTOF mass spectrometer in an urban atmosphere. Additionally, atmospheric naturally charged ions were also measured from November 9 to 22, 2018. Combining the $\mathrm{SO}_{3}$ measurements with data on trace gases, black carbon (BC), traffic flow, and atmospheric ions, we suggest a possible mechanism of formation of $\mathrm{SO}_{3}$ in urban Beijing. We also probe the effects of $\mathrm{SO}_{3}$ on atmospheric $\mathrm{H}_{2} \mathrm{SO}_{4}$ and sub-2.5 nm particle formation.

\section{MATERIALS AND METHODS}

Detection of $\mathrm{SO}_{3}$ and $\mathrm{H}_{2} \mathrm{SO}_{4}$ by a Nitrate-Cl-APiLTOF Mass Spectrometer. The working principle of the nitrate-CI-APi-LTOF mass spectrometer is described in Text S2 and many other studies. ${ }^{5,36}$ The high-resolution peak fit of $\mathrm{SO}_{3} \cdot\left(\mathrm{NO}_{3}^{-}\right)$and its isotope peak $\left[{ }^{34} \mathrm{SO}_{3} \cdot\left(\mathrm{NO}_{3}^{-}\right)\right]$are depicted in Figure S1. The nitrate-CI-APi-LTOF mass spectrometer was calibrated by in situ-generated $\mathrm{SO}_{3}$ and $\mathrm{H}_{2} \mathrm{SO}_{4}{ }^{37}$ (Text S4). The calibration coefficients for $\mathrm{SO}_{3}$ and $\mathrm{H}_{2} \mathrm{SO}_{4}$ are determined to be $1.7 \times 10^{10}$ and $6.1 \times 10^{9} \mathrm{~cm}^{-3}$, respectively (Figure $\mathrm{S} 4$ ). The ratio between the calibration coefficients of $\mathrm{SO}_{3}$ and $\mathrm{H}_{2} \mathrm{SO}_{4}$ is 2.8 , which is consistent with the theoretical prediction of a difference of a factor of 3 in the charging efficiency (Text S5). On the basis of repeat experiments, the $1 \sigma$ of the $\mathrm{SO}_{3}$ calibration coefficient was $\pm 10 \%$.

According to our quantum chemical calculation for the binding thermodynamics of $\mathrm{SO}_{3} \cdot\left(\mathrm{NO}_{3}{ }^{-}\right)$and $\mathrm{HNO}_{3} \cdot\left(\mathrm{NO}_{3}{ }^{-}\right)$ ion-molecule clusters, the electronic binding energy of $\mathrm{SO}_{3}$. $\left(\mathrm{NO}_{3}{ }^{-}\right)$is $-44.4 \mathrm{kcal} / \mathrm{mol}$, which is substantially higher than that of $\mathrm{HNO}_{3} \cdot\left(\mathrm{NO}_{3}{ }^{-}\right)(-29.2 \mathrm{kcal} / \mathrm{mol})$ (Texts $\mathrm{S} 6$ and $\mathrm{S} 7$ and Table S1). Thus, $\mathrm{SO}_{3}$ molecules can be efficiently charged by nitrate ions. The highly favorable ligand exchange reaction between neutral $\mathrm{SO}_{3}$ molecules and nitrate ions can be written as

$$
\mathrm{SO}_{3}+\mathrm{NO}_{3}^{-} \cdot\left(\mathrm{HNO}_{3}\right) \rightarrow \mathrm{SO}_{3} \cdot\left(\mathrm{NO}_{3}{ }^{-}\right)+\mathrm{HNO}_{3}
$$

Furthermore, on the basis of the quantum chemical calculation, reaction $\mathrm{R} 6$ is exothermal by $8.7 \mathrm{kcal} / \mathrm{mol}$ in free energy (Text S6). The lowest-free energy structure for $\mathrm{SO}_{3} \cdot\left(\mathrm{NO}_{3}^{-}\right) \cdot \mathrm{H}_{2} \mathrm{O}$ is depicted in Figure $\mathrm{S} 6$. Therefore, the hydrate complex intermediate $\left(\mathrm{SO}_{3} \cdot \mathrm{H}_{2} \mathrm{O}\right)$ also can be detected as $\mathrm{SO}_{3} \cdot\left(\mathrm{NO}_{3}{ }^{-}\right)$.

$$
\begin{aligned}
& \mathrm{SO}_{3} \cdot \mathrm{H}_{2} \mathrm{O}+\mathrm{NO}_{3}{ }^{-} \cdot\left(\mathrm{HNO}_{3}\right) \\
& \quad \rightarrow \mathrm{SO}_{3} \cdot\left(\mathrm{NO}_{3}{ }^{-}\right) \cdot \mathrm{H}_{2} \mathrm{O}+\mathrm{HNO}_{3}
\end{aligned}
$$

Besides the ligand exchange reaction, the reaction between $\mathrm{SO}_{3}$ and $\mathrm{NO}_{3}{ }^{-}$can also lead to $\mathrm{SO}_{4}{ }^{-}$formation (eq R7). ${ }^{32}$ However, $\mathrm{SO}_{4}^{-}$can also be produced by the reaction of $\mathrm{SO}_{2}$ with $\mathrm{O}_{2}^{-} \cdot\left(\mathrm{H}_{2} \mathrm{O}\right)_{n} \cdot{ }^{34,38}$ From our ambient data, the averaged ratios of $\mathrm{SO}_{4}{ }^{-}$to $\mathrm{SO}_{3} \cdot\left(\mathrm{NO}_{3}{ }^{-}\right)$were $0.26 \pm 0.07$ (winter) and $2.51 \pm 2.60$ (summer). During the summer, a large abundance of $\mathrm{O}_{2}^{-} \cdot\left(\mathrm{H}_{2} \mathrm{O}\right)_{n}$ favored $\mathrm{SO}_{4}{ }^{-}$formation. Hence, only the signal of $\mathrm{SO}_{3} \cdot\left(\mathrm{NO}_{3}{ }^{-}\right)$was taken into account in the $\mathrm{SO}_{3}$ quantification, and it could cause a slight underestimation of $\mathrm{SO}_{3}$ concentrations.

$$
\mathrm{SO}_{3}+\mathrm{NO}_{3}^{-} \rightarrow \mathrm{SO}_{4}^{-}+\mathrm{NO}_{2}
$$

Atmospheric ions were also measured with the CI-APiLTOF mass spectrometer by turning off the chemical ionization unit. Details of other auxiliary measuring instruments for trace gases, BC, meteorological parameters, and sub-3 nm particles can be found in Texts S8 and S9. Also, the calculation of condensation sink (CS) and quantification of $\mathrm{SO}_{3}$ and $\mathrm{H}_{2} \mathrm{SO}_{4}$ were introduced in Texts $\mathrm{S} 10$ and S3.

\section{RESULTS AND DISCUSSION}

Abundance and Diurnal Behavior of $\mathrm{SO}_{3}$ in the Winter and Summer. As shown in Figure 1A, the abundance of $\mathrm{SO}_{3}$ was significantly higher in the winter than in the summer. During the winter, the mixing ratios of $\mathrm{SO}_{3}$ varied from $\sim 4.0 \times 10^{4}$ to $1.9 \times 10^{6}$ molecules $\mathrm{cm}^{-3}$. In comparison, during the summer, $\mathrm{SO}_{3}$ concentrations ranged from $\sim 5.0 \times 10^{3}$ to $1.4 \times 10^{5}$ molecules $\mathrm{cm}^{-3}$. Under $298 \mathrm{~K}$ and $1 \mathrm{~atm}$, the atmospheric $\mathrm{SO}_{3}$ concentration has been proposed to reach $10^{5}$ molecules $\mathrm{cm}^{-3}$ around noon. ${ }^{25}$ In this study, because the influence of ambient ions (i.e., $\mathrm{SO}_{3} \cdot \mathrm{NO}_{3}{ }^{-}$) was not excluded and the hydrate complex intermediate $\left(\mathrm{SO}_{3} \cdot \mathrm{H}_{2} \mathrm{O}\right)$ also could be detected as $\mathrm{SO}_{3} \cdot \mathrm{NO}_{3}{ }^{-}$(eq R6), $\mathrm{SO}_{3}$ concentrations could be overestimated. Median diurnal variations of $\mathrm{SO}_{3}$ and $\mathrm{SO}_{2}$ concentrations, water dimer concentrations $\left[\left(\mathrm{H}_{2} \mathrm{O}\right)_{2}\right.$; computed from the relative humidity and temperature $]^{26,39}$ and intensities of UVB $(280-315 \mathrm{~nm})$ on all measurement days during the winter and summer are illustrated in Figure 1B. The water dimer 

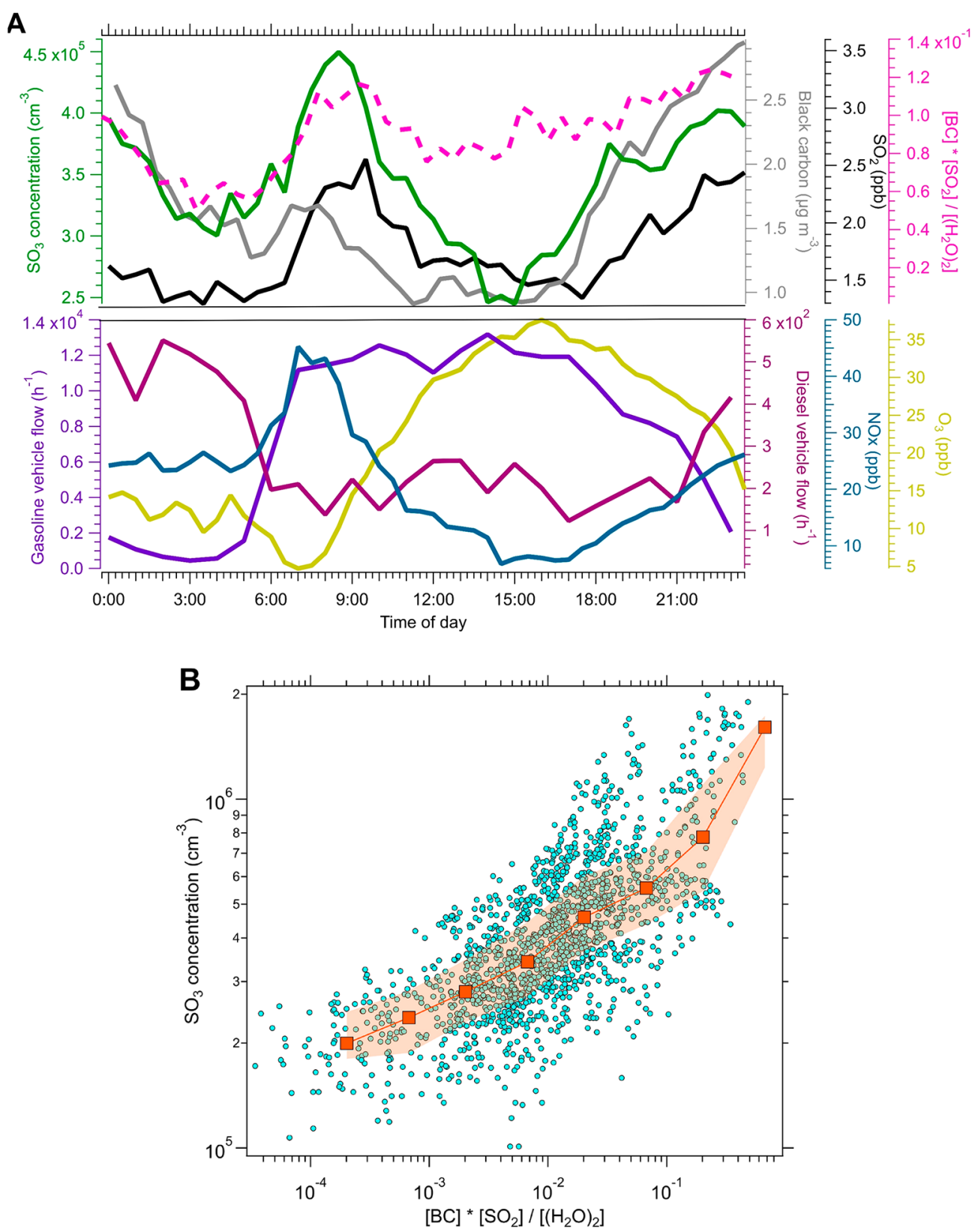

Figure 2. (A) Median diurnal variations in the concentrations of $\mathrm{SO}_{3}, \mathrm{SO}_{2}$, black carbon $(\mathrm{BC}), \mathrm{NO}_{x}$, the approximate abundance term $\left\{\left([\mathrm{BC}]\left[\mathrm{SO}_{2}\right]\right) /\left[\left(\mathrm{H}_{2} \mathrm{O}\right)_{2}\right]\right\}$ of $\mathrm{SO}_{3}$, and gasoline and diesel vehicle flow of the "West Third Ring Road", which was $~ 550 \mathrm{~m}$ to the west of the sampling station in 2017, ${ }^{41}$ and (B) correlation between the $\mathrm{SO}_{3}$ concentration and its approximate abundance term during the night and the early morning (from 18:00 to 08:00 the next day) for the whole field measurement during the winter. In panel $\mathrm{A}$, the units of $\mathrm{BC}$, $\mathrm{SO}_{2}$, and water dimer $\left[\left(\mathrm{H}_{2} \mathrm{O}\right)_{2}\right]$ in approximate source terms were micrograms per cubic meter, molecules per cubic meter, and molecules per cubic meter, respectively. In panel $\mathrm{B}$, the $\mathrm{SO}_{3}$ concentrations were divided into logarithmic bins, and the median values in each bin are shown as squares. The orange shadow represents the values from the 25 th to 75 th percentile.

concentration during the summer was notably higher than during the winter. In contrast, the mixing ratio of $\mathrm{SO}_{2}$ during the summer was lower than that during the winter. In the atmosphere, due to the large abundance of water, it is generally accepted that hydration to $\mathrm{H}_{2} \mathrm{SO}_{4}$ is the main fate of $\mathrm{SO}_{3} \cdot{ }^{24}$ As a second water molecule is needed to lower the barrier of the $\mathrm{SO}_{3}$ hydration reaction, the reaction rate effectively depends on the water dimer concentration. ${ }^{23,40}$ Therefore, the low $\mathrm{SO}_{3}$ concentrations during the summer likely result from the large abundance of the water dimer and low $\mathrm{SO}_{2}$ concentration.
During the winter and summer, $\mathrm{SO}_{3}$ showed similar diurnal patterns (Figure 1B). During the winter, $\mathrm{SO}_{3}$ levels increased from $\sim 05: 00$ and reached their peak at $\sim 08: 30$. The abundance of $\mathrm{SO}_{3}$ was higher during the early morning from $\sim 06: 00$ to $\sim 09: 00$ and night from $\sim 18: 00$ to $\sim 03: 00$ (the next day) than around noon. Similarly, during the summer, $\mathrm{SO}_{3}$ concentrations increased from $\sim 4: 00$ and reached their peak values at $\sim 07: 00$. A peak of $\mathrm{SO}_{3}$ in the early morning ( $\sim$ 04:00 to $\sim 08: 00)$ was also observed. During both the winter and the summer, lower $\mathrm{SO}_{3}$ concentrations were observed around noon when the water dimer concentration reached its minimum level (Figure 1B). 

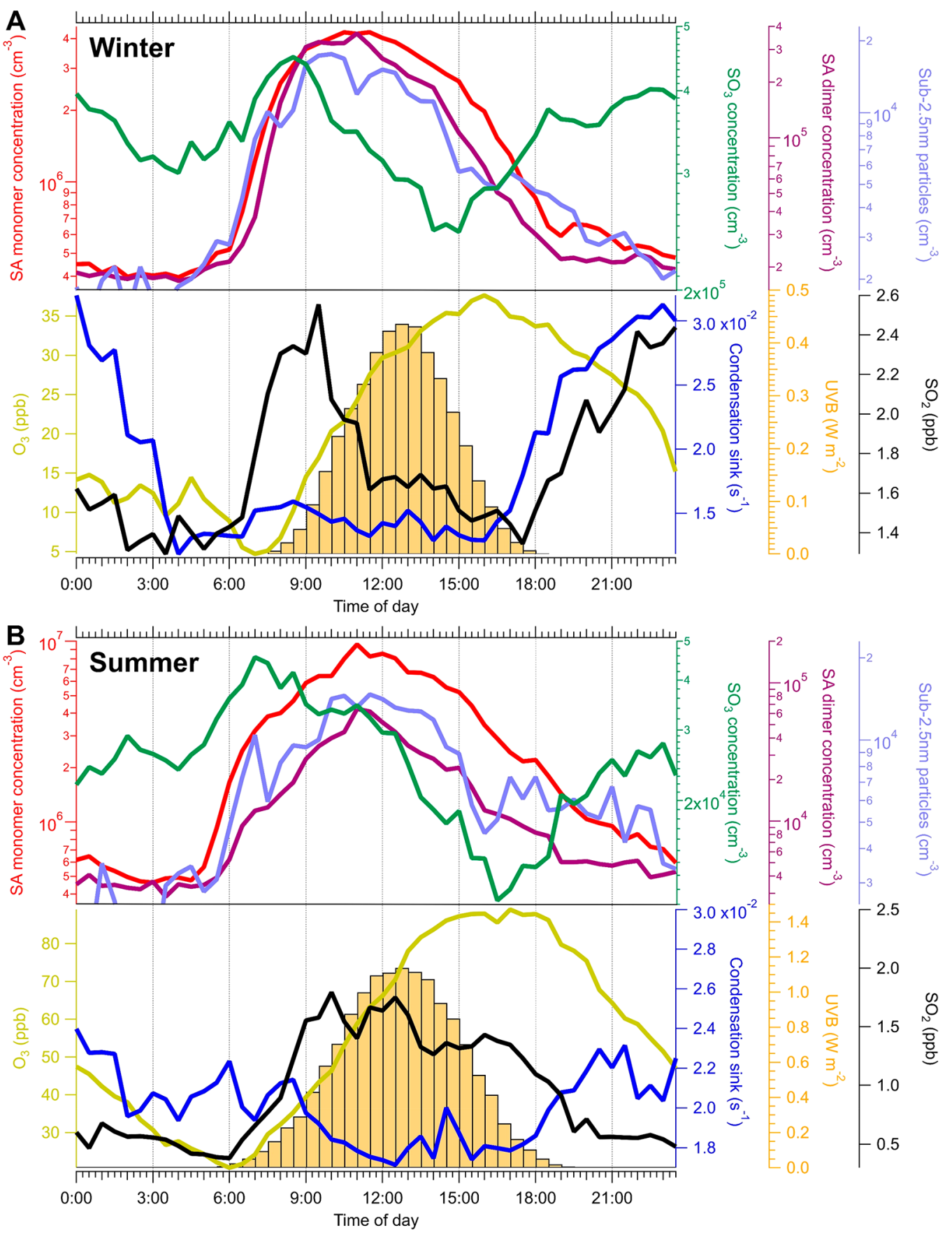

Figure 3. Median diurnal variations in the concentrations and intensities of $\mathrm{SO}_{3}$, the sulfuric acid ( $\left.\mathrm{SA}\right)$ monomer $\left(\mathrm{H}_{2} \mathrm{SO}_{4}\right)$ and dimer, sub-2.5 $\mathrm{nm}$ particles, $\mathrm{SO}_{2}, \mathrm{O}_{3}, \mathrm{UVB}$, and condensation sink (CS) during the (A) winter and (B) summer.

Besides water-catalyzed hydration, around noon, a large abundance of other atmospheric components (e.g., $\mathrm{H}_{2} \mathrm{SO}_{4}$, $\mathrm{HCOOH}, \mathrm{HNO}_{3}$, and oxalic acid) also promoted the conversion of $\mathrm{SO}_{3}$, leading to relatively short lifetimes. In addition, diel patterns of $\mathrm{SO}_{3}$ on nonhaze and haze days in winter are also shown in Figure 1B. The abundance of $\mathrm{SO}_{3}$ exhibited a similar daily pattern during both haze and nonhaze days (Text S8), though the actual values were higher on haze days.

The averaged mass spectra of atmospheric naturally charged ions for a day are shown in Figure S7. The dominant anions in urban Beijing are nitrate ions $\left(\mathrm{NO}_{3}{ }^{-}\right.$and $\mathrm{HNO}_{3} \cdot \mathrm{NO}_{3}{ }^{-}$), similar to the case in Shanghai. ${ }^{5}$ Therefore, the normalized intensity of $\mathrm{SO}_{3} \cdot \mathrm{NO}_{3}{ }^{-}$by the sum of nitrate ions also can represent the abundance of $\mathrm{SO}_{3}$ in the air. Figure $1 \mathrm{C}$ shows the diel variation of the normalized signals of $\mathrm{SO}_{3} \cdot \mathrm{NO}_{3}{ }^{-}$in November 2018. The normalized signals also exhibited two peaks, in the early morning $(\sim 6: 00$ to $\sim 9: 00)$ and at night $(\sim 17: 00$ to $\sim 20: 00)$.

Potential Source Identification for $\mathrm{SO}_{3}$. To investigate the possible sources of $\mathrm{SO}_{3}$ molecules during the early morning and night, we monitored other trace gases $\left(\mathrm{SO}_{2}\right.$ and $\mathrm{NO}_{x}$ ), BC, and traffic flow of the main road nearby. ${ }^{41}$ During the summer, the average $\mathrm{SO}_{3}$ concentration was $2.9 \times 10^{4}$ molecules $\mathrm{cm}^{-3}$, which is likely close to the detection limit of the instrument. Hence, the possible source identification for 
$\mathrm{SO}_{3}$ was focused on winter data. During the winter, the median concentrations of $\mathrm{SO}_{2}, \mathrm{NO}_{x}$, and $\mathrm{BC}$ in $\mathrm{PM}_{2.5}$ exhibited diurnal trends similar to those of $\mathrm{SO}_{3}$ (Figure 2A). On the basis of previous studies of $\mathrm{SO}_{2}$ and together with stable weather conditions (low wind speeds and shallow mixing layer) (Text $\mathrm{S} 11$ and Figure S8), the elevated $\mathrm{SO}_{2}$ concentration during the early morning could mainly be attributed to local emissions (e.g., residential and industry emission) and transportation. ${ }^{42-50}$ BC concentrations were tightly linked with traffic emission dominated by diesel vehicles (Figure 2A).

During the early morning, the UVB intensity was low, which meant that $\mathrm{OH}$ radical concentrations from photochemistry were also low, because of the linear correlation between $\mathrm{OH}$ concentrations and the ozone photolysis frequency $[j(\mathrm{O} 1 \mathrm{D})]$ in Beijing during daytime. ${ }^{51}$ During a summer night in the suburban area of Beijing, $\mathrm{OH}$ radical concentrations from $\sim 0.5$ to $3 \times 10^{6} \mathrm{~cm}^{-3}$ still can be observed. $^{52,53}$ Nevertheless, during the winter in suburban Beijing, the mean observed $\mathrm{OH}$ concentrations were $<3 \times$ $10^{5} \mathrm{~cm}^{-3}$ at night and $<1 \times 10^{6} \mathrm{~cm}^{-3}$ in the early morning (06:00-09:00). ${ }^{54,55}$ Hence, the oxidation of $\mathrm{SO}_{2}$ by $\mathrm{OH}$ radicals was not the main source for $\mathrm{SO}_{3}$ during the early morning and night. In addition, during the early morning, the median ozone concentration was only $\sim 5 \mathrm{ppb}$, which was low in comparison to the values during the rest of the day, resulting in a minor contribution to $\mathrm{SO}_{3}$ production from the reaction between $\mathrm{sCI}$ and $\mathrm{SO}_{2}$. Although $\mathrm{SO}_{3}$ molecules can also be co-emitted with $\mathrm{SO}_{2}$, $^{20-22,56,57}$ transportation is not feasible for $\mathrm{SO}_{3}$ owing to its short lifetime $(<1 \mathrm{~s})$ in the air. Previous studies based on quantum chemical calculations have suggested that the heterogeneous reaction between $\mathrm{SO}_{2}$ and soot can lead to $\mathrm{SO}_{3}$ formation. ${ }^{11,12}$ If this mechanism were to dominate $\mathrm{SO}_{3}$ formation, and further assuming that the $\mathrm{SO}_{3}$ is removed by reaction with the water dimer, the concentration of $\mathrm{SO}_{3}$ would be proportional to ([BC]$\left.\left[\mathrm{SO}_{2}\right]\right) /\left[\left(\mathrm{H}_{2} \mathrm{O}\right)_{2}\right]$. Figure $2 \mathrm{~A}$ shows that during the early morning (06:00-09:00) and night (from 18:00 to 6:00 the next day), the median diurnal variations of $\mathrm{SO}_{3}$ and $\left([\mathrm{BC}]\left[\mathrm{SO}_{2}\right]\right) /\left[\left(\mathrm{H}_{2} \mathrm{O}\right)_{2}\right]$ were consistent with each other. Also, for the whole measurement period during the winter from 18:00 to 08:00 the next day, the correlation between $\mathrm{SO}_{3}$ and this approximate abundance term was positive $[r=$ 0.7; $P<0.0001$ (Figure 2B)]. Furthermore, on nonhaze days, $\mathrm{SO}_{3}$ was tightly linked to particulate sulfate, implying $\mathrm{SO}_{3}$ may originate from heterogeneous reaction (Figure S9). Therefore, our results together suggested the heterogeneous reaction between $\mathrm{SO}_{2}$ and $\mathrm{BC}$ could be the possible source of $\mathrm{SO}_{3}$ during the early morning and at night. However, other formation mechanisms (e.g., Criegee intermediate and $\mathrm{SO}_{2}$ ) may also contribute. 9

Enhancement of Sulfuric Acid and Sub-2.5 nm Particle Formation. Median diurnal variations of the concentrations or intensities of $\mathrm{H}_{2} \mathrm{SO}_{4}$, the sulfuric acid dimer $\left(\mathrm{H}_{2} \mathrm{SO}_{4} \cdot \mathrm{HSO}_{4}{ }^{-}\right), \mathrm{SO}_{3}$, sub- $2.5 \mathrm{~nm}$ particles, $\mathrm{CS}, \mathrm{SO}_{2}$, ozone, and UVB during the winter and summer are shown in panels A and B of Figure 3A and B, respectively. During the winter and summer, elevated levels of $\mathrm{SO}_{3}$ and $\mathrm{H}_{2} \mathrm{SO}_{4}$ were simultaneously observed in the early morning. During the winter, the median concentrations of $\mathrm{H}_{2} \mathrm{SO}_{4}$ during the early morning were comparable with that around noon. In addition, it showed a good correlation $(r=0.7)$ between atmospheric ions of $\mathrm{HSO}_{4}{ }^{-}$and $\mathrm{SO}_{3} \cdot \mathrm{NO}_{3}{ }^{-}$during the early morning (5:00-8:00) and night (from 18:00 to 5:00 the following day) (Figure S10). Thus, the $\mathrm{SO}_{3}$ formed from nonphotochemical processes enhanced $\mathrm{H}_{2} \mathrm{SO}_{4}$ formation during the early morning and night. In a recent study in urban Beijing, under clean conditions, oxidation of $\mathrm{SO}_{2}$ by oxidants produced in the ozonolysis of alkenes (i.e., sCI and "dark" $\mathrm{OH}$ ) was suggested as a source of $\mathrm{H}_{2} \mathrm{SO}_{4}$ during the night. $^{58}$ This study also pointed out that, under polluted conditions, additional sources of $\mathrm{H}_{2} \mathrm{SO}_{4}$ exist. Hence, during the night in urban Beijing, $\mathrm{H}_{2} \mathrm{SO}_{4}$ can be enhanced both by $\mathrm{SO}_{3}$ molecules produced by the heterogeneous reaction between $\mathrm{BC}$ and $\mathrm{SO}_{2}$ and by the oxidation of $\mathrm{SO}_{2}$ by oxidants from ozonolysis of alkenes.

As shown in Figure 3, during the winter or summer, the median concentrations of $\mathrm{H}_{2} \mathrm{SO}_{4}, \mathrm{H}_{2} \mathrm{SO}_{4} \cdot \mathrm{HSO}_{4}{ }^{-}$, and sub- 2.5 $\mathrm{nm}$ particles followed the same diurnal behavior. The concentrations of $\mathrm{H}_{2} \mathrm{SO}_{4} \cdot \mathrm{HSO}_{4}{ }^{-}$and sub-2.5 nm particles started to increase at $\sim 5: 00$. During the early morning during the winter, the median concentrations of $\mathrm{H}_{2} \mathrm{SO}_{4} \cdot \mathrm{HSO}_{4}{ }^{-}$and sub-2.5 nm particles were comparable with that around noon. On the basis of the studies in urban Shanghai, if atmospheric bases were abundant, the sulfuric acid dimer could be treated as an indicator of nanocluster formation. ${ }^{5,59}$ In urban Beijing, the concentrations of atmospheric bases (e.g., amines and ammonia) may also be sufficient for efficient clustering. Thus, the increased level of formation of $\mathrm{SO}_{3}$, possibly produced by the oxidation of $\mathrm{SO}_{2}$ on top of soot particles, can intensify the production of secondary particles and enhance gas to particle conversion during the early morning and night. We note that the contribution to nanoclusters of traffic, or the reaction of $\mathrm{SO}_{3}$ with ammonia/methanol, cannot be wholly excluded. ${ }^{25,60-62}$ Our results together point toward the need to control the emission of $\mathrm{SO}_{2}$ and soot to mitigate secondary aerosol formation in urban Beijing.

\section{ASSOCIATED CONTENT}

\section{Supporting Information}

The Supporting Information is available free of charge at https://pubs.acs.org/doi/10.1021/acs.estlett.0c00615.

Description of the sampling site (Text S1), the nitrateCI-APi-LTOF mass spectrometer (Text S2), detection of sulfuric acid with nitrate reagent ions (Text S3), detailed calibration experiment for $\mathrm{SO}_{3}$ (Text S4), quantum chemical calculations (Text S6), computational details (Text S7), $\mathrm{PM}_{2.5}$, black carbon, particulate sulfate, trace gases, meteorological parameters, and UVB measurements (Text S8), sub-3 nm particle measurements (Text S9), calculation of condensation sink (Text S10), source identification of $\mathrm{SO}_{2}$ during the winter (Text S11), high-resolution peak fitting of the ${ }^{32} \mathrm{SO}_{3} \cdot \mathrm{NO}_{3}{ }^{-}$peak and its ${ }^{34} \mathrm{SO}_{3} \cdot \mathrm{NO}_{3}{ }^{-}$main isotope peak (Figure S1), schematic of the calibration experiment setup (Figure S2), time series of normalized signals of $\mathrm{H}_{2} \mathrm{SO}_{4}$ and $\mathrm{SO}_{3}$, and $\left[\mathrm{H}_{2} \mathrm{O}\right]$ in the calibration experiment (Figure S3), correlation between normalized $\mathrm{SO}_{3}$ signals measured by the CI-APi-LTOF mass spectrometer and $\mathrm{SO}_{3}$ concentrations formed by photo-oxidation of $\mathrm{SO}_{2}$ by $\mathrm{OH}$ radicals (Figure $\mathrm{S} 4$ ), optimized structure of the $\mathrm{SO}_{3} \cdot\left(\mathrm{NO}_{3}{ }^{-}\right)$cluster (Figure $\mathrm{S5}$ ), lowest-free energy (at $298 \mathrm{~K}$ ) structure found for $\mathrm{SO}_{3} \cdot\left(\mathrm{NO}_{3}^{-}\right) \cdot \mathrm{H}_{2} \mathrm{O}$ (Figure $\mathrm{S} 6$ ), averaged mass spectra of atmospheric naturally charged ions for one whole 
day (November 10, 2018) (Figure S7), median diurnal variation of the concentrations of $\mathrm{SO}_{3}$ and $\mathrm{SO}_{2}$, the mixing layer heights (MLH), intensities of UVB, and wind speeds during the winter (Figure S8), time profile of the $\mathrm{SO}_{3}$ concentration and mass concentration of sulfate in $\mathrm{PM}_{2.5}$ and median diel variation of $\mathrm{SO}_{3}$ and sulfate for all nonhaze days during the winter measurement period (Figure S9), relationship between the atmospheric ion signals of $\mathrm{HSO}_{4}{ }^{-}$and $\mathrm{SO}_{3} \cdot \mathrm{NO}_{3}{ }^{-}$ during the night (from 18:00 to 5:00 next day) and early morning (5:00-8:00) from November 9 to 22, 2018 (Figure $\mathrm{S} 10$ ), and comparison of the binding thermodynamics of $\mathrm{HNO}_{3} \cdot\left(\mathrm{NO}_{3}{ }^{-}\right)$and $\mathrm{SO}_{3} \cdot\left(\mathrm{NO}_{3}{ }^{-}\right)$ ion-molecule clusters (Table S1) (PDF)

\section{AUTHOR INFORMATION}

\section{Corresponding Authors}

Federico Bianchi - Aerosol and Haze Laboratory, Beijing Advanced Innovation Center for Soft Matter Science and Engineering, Beijing University of Chemical Technology, Beijing 100089, China; Institute for Atmospheric and Earth System Research/Physics, Faculty of Science, University of Helsinki, Helsinki 00560, Finland; ○ orcid.org/0000-0003-29963604; Email: federico.bianchi@helsinki.fi

Markku Kulmala - Aerosol and Haze Laboratory, Beijing Advanced Innovation Center for Soft Matter Science and Engineering, Beijing University of Chemical Technology, Beijing 100089, China; Institute for Atmospheric and Earth System Research/Physics, Faculty of Science, University of Helsinki, Helsinki 00560, Finland; Joint International Research Laboratory of Atmospheric and Earth System Sciences (JirLATEST), Nanjing University, Nanjing 210023, China; Email: markku.kulmala@helsinki.fi

Hong He - State Key Joint Laboratory of Environment Simulation and Pollution Control, Research Center for EcoEnvironmental Sciences and Center for Excellence in Regional Atmospheric Environment, Institute of Urban Environment, Chinese Academy of Sciences, Beijing 100085, China; Email: honghe@rcees.ac.cn

\section{Authors}

Lei Yao - Aerosol and Haze Laboratory, Beijing Advanced Innovation Center for Soft Matter Science and Engineering, Beijing University of Chemical Technology, Beijing 100089, China; Institute for Atmospheric and Earth System Research/ Physics, Faculty of Science, University of Helsinki, Helsinki 00560, Finland; 이이. orid.org/0000-0002-2680-1629

Xiaolong Fan - Aerosol and Haze Laboratory, Beijing Advanced Innovation Center for Soft Matter Science and Engineering, Beijing University of Chemical Technology, Beijing 100089, China

Chao Yan - Institute for Atmospheric and Earth System Research/Physics, Faculty of Science, University of Helsinki, Helsinki 00560, Finland

Theo Kurtén - Department of Chemistry, University of Helsinki, Helsinki 00014, Finland; 이 orcid.org/0000-00026416-4931

Kaspar R. Daellenbach - Institute for Atmospheric and Earth System Research/Physics, Faculty of Science, University of Helsinki, Helsinki 00560, Finland

Chang Li - Aerosol and Haze Laboratory, Beijing Advanced Innovation Center for Soft Matter Science and Engineering,
Beijing University of Chemical Technology, Beijing 100089, China

Yonghong Wang - Institute for Atmospheric and Earth System Research/Physics, Faculty of Science, University of Helsinki, Helsinki 00560, Finland

Yishuo Guo - Aerosol and Haze Laboratory, Beijing Advanced Innovation Center for Soft Matter Science and Engineering, Beijing University of Chemical Technology, Beijing 100089, China

Lubna Dada - Institute for Atmospheric and Earth System Research/Physics, Faculty of Science, University of Helsinki, Helsinki 00560, Finland

Matti P. Rissanen - Aerosol Physics Laboratory, Physics Unit, Tampere University, Tampere 33100, Finland; 이이. org/ 0000-0003-0463-8098

Jing Cai - Institute for Atmospheric and Earth System Research/Physics, Faculty of Science, University of Helsinki, Helsinki 00560, Finland

Yee Jun Tham - Institute for Atmospheric and Earth System Research/Physics, Faculty of Science, University of Helsinki, Helsinki 00560, Finland

Qiaozhi Zha - Institute for Atmospheric and Earth System Research/Physics, Faculty of Science, University of Helsinki, Helsinki 00560, Finland

Shaojun Zhang - State Key Joint Laboratory of Environment Simulation and Pollution Control, State Environmental Protection Key Laboratory of Sources and Control of Air Pollution Complex, School of Environment, Tsinghua University, Beijing 100084, China; orcid.org/0000-00022176-6174

Wei Du - Institute for Atmospheric and Earth System Research/Physics, Faculty of Science, University of Helsinki, Helsinki 00560, Finland

Miao Yu - Institute of Urban Meteorology, China Meteorological Administration, Beijing 100081, China

Feixue Zheng - Aerosol and Haze Laboratory, Beijing Advanced Innovation Center for Soft Matter Science and Engineering, Beijing University of Chemical Technology, Beijing 100089, China

Ying Zhou - Aerosol and Haze Laboratory, Beijing Advanced Innovation Center for Soft Matter Science and Engineering, Beijing University of Chemical Technology, Beijing 100089, China

Jenni Kontkanen - Institute for Atmospheric and Earth System Research/Physics, Faculty of Science, University of Helsinki, Helsinki 00560, Finland

Tommy Chan - Institute for Atmospheric and Earth System Research/Physics, Faculty of Science, University of Helsinki, Helsinki 00560, Finland

Jiali Shen - Institute for Atmospheric and Earth System Research/Physics, Faculty of Science, University of Helsinki, Helsinki 00560, Finland

Joni T. Kujansuu - Aerosol and Haze Laboratory, Beijing Advanced Innovation Center for Soft Matter Science and Engineering, Beijing University of Chemical Technology, Beijing 100089, China; Institute for Atmospheric and Earth System Research/Physics, Faculty of Science, University of Helsinki, Helsinki 00560, Finland

Juha Kangasluoma - Aerosol and Haze Laboratory, Beijing Advanced Innovation Center for Soft Matter Science and Engineering, Beijing University of Chemical Technology, Beijing 100089, China; Institute for Atmospheric and Earth System 
Research/Physics, Faculty of Science, University of Helsinki, Helsinki 00560, Finland; 10 orcid.org/0000-0002-1639-1187

Jingkun Jiang - State Key Joint Laboratory of Environment Simulation and Pollution Control, State Environmental Protection Key Laboratory of Sources and Control of Air Pollution Complex, School of Environment, Tsinghua University, Beijing 100084, China

Lin Wang - Shanghai Key Laboratory of Atmospheric Particle Pollution and Prevention (LAP3), Department of Environmental Science \& Engineering, Fudan University, Shanghai 200438, China; $\odot$ orcid.org/0000-0002-49053432

Douglas R. Worsnop - Aerodyne Research Inc., Billerica, Massachusetts 01821, United States

Tuukka Petäjä - Institute for Atmospheric and Earth System Research/Physics, Faculty of Science, University of Helsinki, Helsinki 00560, Finland

Veli-Matti Kerminen - Institute for Atmospheric and Earth System Research/Physics, Faculty of Science, University of Helsinki, Helsinki 00560, Finland

Yongchun Liu - Aerosol and Haze Laboratory, Beijing Advanced Innovation Center for Soft Matter Science and Engineering, Beijing University of Chemical Technology, Beijing 100089, China; orcid.org/0000-0002-9055-970X

Biwu Chu - Institute for Atmospheric and Earth System Research/Physics, Faculty of Science, University of Helsinki, Helsinki 00560, Finland; State Key Joint Laboratory of Environment Simulation and Pollution Control, Research Center for Eco-Environmental Sciences and Center for Excellence in Regional Atmospheric Environment, Institute of Urban Environment, Chinese Academy of Sciences, Beijing 100085, China; ○ orcid.org/0000-0002-7548-5669

Complete contact information is available at: https://pubs.acs.org/10.1021/acs.estlett.0c00615

\section{Author Contributions}

L.Y. and X.F. contributed equally to this work. L.Y. and F.B. designed the research and analyzed the data. L.Y., C.Y., Y.G., C.L., X.F., Y.Z., K.R.D., F.Z., Y.W., and T.C. performed the measurements for this study. T.K. provided quantum calculation results. L.Y., X.F., B.C., F.B., T.P., M.P.R., L.W., Y.L., J.J., D.R.W., V.-M.K., T.K., and M.K. interpreted the results and revised the manuscript. M.K., F.B., and H.H. supported and supervised this research. L.Y. wrote the manuscript with contributions from all co-authors.

\section{Notes}

The authors declare no competing financial interest.

\section{ACKNOWLEDGMENTS}

The work is supported by Academy of Finland (Center of Excellence in Atmospheric Sciences, project no. 307331, and PROFI3 funding, 311932), the European Research Council via ATM-GTP (742206) and via CHAPAs (850614) and the EMME-CARE project which has received funding from the European Union's Horizon 2020 Research and Innovation Programme, under Grant Agreement No. 856612.

\section{REFERENCES}

(1) Larssen, T.; Lydersen, E.; Tang, D. G.; He, Y.; Gao, J. X.; Liu, H. Y.; Duan, L.; Seip, H. M.; Vogt, R. D.; Mulder, J.; Shao, M.; Wang, Y. H.; Shang, H.; Zhang, X. S.; Solberg, S.; Aas, W.; Okland, T.; Eilertsen, O.; Angell, V.; Li, Q. R.; Zhao, D. W.; Xiang, R. J.;
Xiao, J. S.; Luo, J. H. Acid rain in China. Environ. Sci. Technol. 2006, 40 (2), 418-425.

(2) Sipilä, M.; Berndt, T.; Petäjä, T.; Brus, D.; Vanhanen, J.; Stratmann, F.; Patokoski, J.; Mauldin, R. L.; Hyvarinen, A. P.; Lihavainen, H.; Kulmala, M. The Role of Sulfuric Acid in Atmospheric Nucleation. Science 2010, 327 (5970), 1243-1246.

(3) Kulmala, M.; Kontkanen, J.; Junninen, H.; Lehtipalo, K.; Manninen, H. E.; Nieminen, T.; Petäjä, T.; Sipilä, M.; Schobesberger, S.; Rantala, P.; Franchin, A.; Jokinen, T.; Jarvinen, E.; Aijala, M.; Kangasluoma, J.; Hakala, J.; Aalto, P. P.; Paasonen, P.; Mikkila, J.; Vanhanen, J.; Aalto, J.; Hakola, H.; Makkonen, U.; Ruuskanen, T.; Mauldin, R. L.; Duplissy, J.; Vehkamaki, H.; Back, J.; Kortelainen, A.; Riipinen, I.; Kurtén, T.; Johnston, M. V.; Smith, J. N.; Ehn, M.; Mentel, T. F.; Lehtinen, K. E.; Laaksonen, A.; Kerminen, V. M.; Worsnop, D. R. Direct observations of atmospheric aerosol nucleation. Science 2013, 339 (6122), 943-6.

(4) Bianchi, F.; Tröstl, J.; Junninen, H.; Frege, C.; Henne, S.; Hoyle, C. R.; Molteni, U.; Herrmann, E.; Adamov, A.; Bukowiecki, N.; Chen, X.; Duplissy, J.; Gysel, M.; Hutterli, M.; Kangasluoma, J.; Kontkanen, J.; Kurten, A.; Manninen, H. E.; Munch, S.; Perakyla, O.; Petäjä, T.; Rondo, L.; Williamson, C.; Weingartner, E.; Curtius, J.; Worsnop, D. R.; Kulmala, M.; Dommen, J.; Baltensperger, U. New particle formation in the free troposphere: A question of chemistry and timing. Science 2016, 352 (6289), 1109-1112.

(5) Yao, L.; Garmash, O.; Bianchi, F.; Zheng, J.; Yan, C.; Kontkanen, J.; Junninen, H.; Mazon, S. B.; Ehn, M.; Paasonen, P.; Sipilä, M.; Wang, M.; Wang, X.; Xiao, S.; Chen, H.; Lu, Y.; Zhang, B.; Wang, D.; Fu, Q.; Geng, F.; Li, L.; Wang, H.; Qiao, L.; Yang, X.; Chen, J.; Kerminen, V. M.; Petäjä, T.; Worsnop, D. R.; Kulmala, M.; Wang, L. Atmospheric new particle formation from sulfuric acid and amines in a Chinese megacity. Science 2018, 361 (6399), 278-281.

(6) Chu, B. W.; Kerminen, V. M.; Bianchi, F.; Yan, C.; Petäjä, T.; Kulmala, M. Atmospheric new particle formation in China. Atmos. Chem. Phys. 2019, 19 (1), 115-138.

(7) Chen, H.; Wang, M.; Yao, L.; Chen, J.; Wang, L. Uptake of Gaseous Alkylamides by Suspended Sulfuric Acid Particles: Formation of Ammonium/Aminium Salts. Environ. Sci. Technol. 2017, 51 (20), 11710-11717.

(8) Kerminen, V. M.; Chen, X. M.; Vakkari, V.; Petäjä, T.; Kulmala, M.; Bianchi, F. Atmospheric new particle formation and growth: review of field observations. Environ. Res. Lett. 2018, 13 (10), 103003

(9) Mauldin, R. L.; Berndt, T.; Sipilä, M.; Paasonen, P.; Petäjä, T.; Kim, S.; Kurtén, T.; Stratmann, F.; Kerminen, V. M.; Kulmala, M. A new atmospherically relevant oxidant of sulphur dioxide. Nature 2012, 488 (7410), 193-196.

(10) Welz, O.; Savee, J. D.; Osborn, D. L.; Vasu, S. S.; Percival, C. J.; Shallcross, D. E.; Taatjes, C. A. Direct Kinetic Measurements of Criegee Intermediate $\left(\mathrm{CH}_{2} \mathrm{OO}\right)$ Formed by Reaction of $\mathrm{CH}_{2} \mathrm{I}$ with $\mathrm{O}_{2}$. Science 2012, 335 (6065), 204-207.

(11) He, G. Z.; He, H. DFT studies on the heterogeneous oxidation of $\mathrm{SO}_{2}$ by oxygen functional groups on graphene. Phys. Chem. Chem. Phys. 2016, 18 (46), 31691-31697.

(12) He, G. Z.; Ma, J. Z.; He, H. Role of Carbonaceous Aerosols in Catalyzing Sulfate Formation. ACS Catal. 2018, 8 (5), 38253832.

(13) Lizzio, A. A.; DeBarr, J. A. Mechanism of $\mathrm{SO}_{2}$ removal by carbon. Energy Fuels 1997, 11 (2), 284-291.

(14) Han, C.; Liu, Y. C.; Ma, J. Z.; He, H. Key role of organic carbon in the sunlight-enhanced atmospheric aging of soot by $\mathrm{O}_{2}$. Proc. Natl. Acad. Sci. U. S. A. 2012, 109 (52), 21250-21255.

(15) He, G.; He, H. Water Promotes the Oxidation of $\mathrm{SO}_{2}$ by $\mathrm{O}_{2}$ over Carbonaceous Aerosols. Environ. Sci. Technol. 2020, 54 (12), $7070-7077$.

(16) Novakov, T.; Chang, S. G.; Harker, A. B. Sulfates as Pollution Particulates - Catalytic Formation on Carbon (soot) Particles. Science 1974, 186 (4160), 259-261.

(17) Zhao, Y.; Liu, Y. C.; Ma, J. Z.; Ma, Q. X.; He, H. Heterogeneous reaction of $\mathrm{SO}_{2}$ with soot: The roles of relative 
humidity and surface composition of soot in surface sulfate formation. Atmos. Environ. 2017, 152, 465-476.

(18) He, X.; Pang, S. F.; Ma, J. B.; Zhang, Y. H. Influence of relative humidity on heterogeneous reactions of $\mathrm{O}_{3}$ and $\mathrm{O}_{3} / \mathrm{SO}_{2}$ with soot particles: Potential for environmental and health effects. Atmos. Environ. 2017, 165, 198-206.

(19) Zhang, F.; Wang, Y.; Peng, J.; Chen, L.; Sun, Y.; Duan, L.; Ge, X.; Li, Y.; Zhao, J.; Liu, C.; Zhang, X.; Zhang, G.; Pan, Y.; Wang, Y.; Zhang, A. L.; Ji, Y.; Wang, G.; Hu, M.; Molina, M. J.; Zhang, R. An unexpected catalyst dominates formation and radiative forcing of regional haze. Proc. Natl. Acad. Sci. U. S. A. 2020, 117 (8), 3960-3966.

(20) Shen, J. L.; Zheng, C. H.; Xu, L. J.; Zhang, Y.; Zhang, Y. X.; Liu, S. J.; Gao, X. Atmospheric emission inventory of $\mathrm{SO}_{3}$ from coalfired power plants in China in the period 2009-2014. Atmos. Environ. 2019, 197, 14-21.

(21) Yang, Z.; Ji, P.; Li, Q.; Jiang, Y.; Zheng, C.; Wang, Y.; Gao, $\mathrm{X}$; Lin, R. Comprehensive understanding of $\mathrm{SO}_{3}$ effects on synergies among air pollution control devices in ultra-low emission power plants burning high-sulfur coal. J. Cleaner Prod. 2019, 239, 118096.

(22) Roy, B.; Chen, L. G.; Bhattacharya, S. Nitrogen Oxides, Sulfur Trioxide, and Mercury Emissions during Oxyfuel Fluidized Bed Combustion of Victorian Brown Coal. Environ. Sci. Technol. 2014, 48 (24), 14844-14850.

(23) Morokuma, K.; Muguruma, C. Ab-Initio Molecular-Orbital Study of the Mechanism of the Gas-Phase Reaction $\mathrm{SO}_{3}+\mathrm{H}_{2} \mathrm{O}$ Importance of the 2nd Water Molecule. J. Am. Chem. Soc. 1994, 116 (22), 10316-10317.

(24) Kolb, C. E.; Jayne, J. T.; Worsnop, D. R.; Molina, M. J.; Meads, R. F.; Viggiano, A. A. Gas-Phase Reaction of Sulfur-Trioxide with Water-Vapor. J. Am. Chem. Soc. 1994, 116 (22), 10314-10315.

(25) Li, H.; Zhong, J.; Vehkamaki, H.; Kurten, T.; Wang, W. G.; Ge, M. F.; Zhang, S. W.; Li, Z. S.; Zhang, X. H.; Francisco, J. S.; Zeng, X. C. Self-Catalytic Reaction of $\mathrm{SO}_{3}$ and $\mathrm{NH}_{3}$ To Produce Sulfamic Acid and Its Implication to Atmospheric Particle Formation. J. Am. Chem. Soc. 2018, 140 (35), 11020-11028.

(26) Sarkar, S.; Oram, B. K.; Bandyopadhyay, B. Influence of Ammonia and Water on the Fate of Sulfur Trioxide in the Troposphere: Theoretical Investigation of Sulfamic Acid and Sulfuric Acid Formation Pathways. J. Phys. Chem. A 2019, 123 (14), 3131-3141.

(27) Lv, G. C.; Sun, X. M.; Zhang, C. X.; Li, M. Understanding the catalytic role of oxalic acid in $\mathrm{SO}_{3}$ hydration to form $\mathrm{H}_{2} \mathrm{SO}_{4}$ in the atmosphere. Atmos. Chem. Phys. 2019, 19 (5), 2833-2844.

(28) Bandyopadhyay, B.; Kumar, P.; Biswas, P. Ammonia Catalyzed Formation of Sulfuric Acid in Troposphere: The Curious Case of a Base Promoting Acid Rain. J. Phys. Chem. A 2017, 121 (16), 3101-3108.

(29) Long, B.; Chang, C. R.; Long, Z. W.; Wang, Y. B.; Tan, X. F.; Zhang, W. J. Nitric acid catalyzed hydrolysis of $\mathrm{SO}_{3}$ in the formation of sulfuric acid: A theoretical study. Chem. Phys. Lett. 2013, 581, 26-29.

(30) Fleig, D.; Vainio, E.; Andersson, K.; Brink, A.; Johnsson, F.; Hupa, M. Evaluation of SO3Measurement Techniques in Air and Oxy-Fuel Combustion. Energy Fuels 2012, 26 (9), 5537-5549.

(31) Lovejoy, E. R.; Hanson, D. R.; Huey, L. G. Kinetics and products of the gas-phase reaction of $\mathrm{SO}_{3}$ with water. J. Phys. Chem. 1996, 100 (51), 19911-19916.

(32) Arnold, S. T.; Morris, R. A.; Viggiano, A. A.; Jayne, J. T. Ion Chemistry Relevant for Chemical-Ionization Detection of $\mathrm{SO}_{3}$. J. Geophys. Res. 1995, 100 (D7), 14141-14146.

(33) Jayne, J. T.; Poschl, U.; Chen, Y. M.; Dai, D.; Molina, L. T.; Worsnop, D. R.; Kolb, C. E.; Molina, M. J. Pressure and temperature dependence of the gas-phase reaction of $\mathrm{SO}_{3}$ with $\mathrm{H}_{2} \mathrm{O}$ and the heterogeneous reaction of $\mathrm{SO}_{3}$ with $\mathrm{H}_{2} \mathrm{O} / \mathrm{H}_{2} \mathrm{SO}_{4}$ surfaces. J. Phys. Chem. A 1997, 101 (51), 10000-10011.

(34) Sorokin, A.; Katragkou, E.; Arnold, F.; Busen, R.; Schumann, $\mathrm{U}$. Gaseous $\mathrm{SO}_{3}$ and $\mathrm{H}_{2} \mathrm{SO}_{4}$ in the exhaust of an aircraft gas turbine engine: measurements by CIMS and implications for fuel sulfur conversion to sulfur (VI) and conversion of $\mathrm{SO}_{3}$ to $\mathrm{H}_{2} \mathrm{SO}_{4}$. Atmos. Environ. 2004, 38 (3), 449-456.

(35) Berndt, T.; Scholz, W.; Mentler, B.; Fischer, L.; Hoffmann, E. H.; Tilgner, A.; Hyttinen, N.; Prisle, N. L.; Hansel, A.; Herrmann, $\mathrm{H}$. Fast Peroxy Radical Isomerization and $\mathrm{OH}$ Recycling in the Reaction of $\mathrm{OH}$ Radicals with Dimethyl Sulfide. J. Phys. Chem. Lett. 2019, 10 (21), 6478-6483.

(36) Jokinen, T.; Sipilä, M.; Junninen, H.; Ehn, M.; Lönn, G.; Hakala, J.; Petäjä, T.; Mauldin, R. L.; Kulmala, M.; Worsnop, D. R. Atmospheric sulphuric acid and neutral cluster measurements using CI-APi-TOF. Atmos. Chem. Phys. 2012, 12 (9), 4117-4125.

(37) Kürten, A.; Rondo, L.; Ehrhart, S.; Curtius, J. Calibration of a chemical ionization mass spectrometer for the measurement of gaseous sulfuric acid. J. Phys. Chem. A 2012, 116 (24), 6375-86.

(38) Mohler, O.; Reiner, T.; Arnold, F. The Formation of $\mathrm{SO}_{5}{ }^{-}$by Gas-Phase Ion-Molecule Reactions. J. Chem. Phys. 1992, 97 (11), 8233-8239.

(39) Anglada, J. M.; Hoffman, G. J.; Slipchenko, L. V.; Costa, M. M.; Ruiz-Lopez, M. F.; Francisco, J. S. Atmospheric Significance of Water Clusters and Ozone-Water Complexes. J. Phys. Chem. A 2013, 117 (40), 10381-10396.

(40) Larson, L. J.; Kuno, M.; Tao, F. M. Hydrolysis of sulfur trioxide to form sulfuric acid in small water clusters. J. Chem. Phys. 2000, 112 (20), 8830-8838.

(41) Yang, D. Y.; Zhang, S. J.; Niu, T. L.; Wang, Y. J.; Xu, H. L.; Zhang, K. M.; Wu, Y. High-resolution mapping of vehicle emissions of atmospheric pollutants based on large-scale, real-world traffic datasets. Atmos. Chem. Phys. 2019, 19 (13), 8831-8843.

(42) Xu, W. Y.; Zhao, C. S.; Ran, L.; Lin, W. L.; Yan, P.; Xu, X. B. $\mathrm{SO}_{2}$ noontime-peak phenomenon in the North China Plain. Atmos. Chem. Phys. 2014, 14 (15), 7757-7768.

(43) Liu, J.; Mauzerall, D. L.; Chen, Q.; Zhang, Q.; Song, Y.; Peng, W.; Klimont, Z.; Qiu, X. H.; Zhang, S. Q.; Hu, M.; Lin, W. L.; Smith, K. R.; Zhu, T. Air pollutant emissions from Chinese households: A major and underappreciated ambient pollution source. Proc. Natl. Acad. Sci. U. S. A. 2016, 113 (28), 7756-7761.

(44) Li, R.; Fu, H. B.; Cui, L. L.; Li, J. L.; Wu, Y.; Meng, Y.; Wang, Y. T.; Chen, J. M. The spatiotemporal variation and key factors of $\mathrm{SO}_{2}$ in 336 cities across China. J. Cleaner Prod. 2019, 210, $602-611$.

(45) Huang, Q.; Cheng, S. Y.; Perozzi, R. E.; Perozzi, E. F. Use of a MM5-CAMx-PSAT Modeling System to Study $\mathrm{SO}_{2}$ Source Apportionment in the Beijing Metropolitan Region. Environ. Model. Assess. 2012, 17 (5), 527-538.

(46) Kampa, M.; Castanas, E. Human health effects of air pollution. Environ. Pollut. 2008, 151 (2), 362-367.

(47) Zhong, Q. R.; Shen, H. Z.; Yun, X.; Chen, Y. L.; Ren, Y. A.; Xu, H. R.; Shen, G. F.; Ma, J. M.; Tao, S. Effects of International Fuel Trade on Global Sulfur Dioxide Emissions. Environ. Sci. Technol. Lett. 2019, 6 (12), 727-731.

(48) Klimont, Z.; Smith, S. J.; Cofala, J. The last decade of global anthropogenic sulfur dioxide: 2000-2011 emissions. Environ. Res. Lett. 2013, 8 (1), 014003.

(49) Su, S. S.; Li, B. G.; Cui, S. Y.; Tao, S. Sulfur Dioxide Emissions from Combustion in China: From 1990 to 2007. Environ. Sci. Technol. 2011, 45 (19), 8403-8410.

(50) Zheng, H. T.; Cai, S. Y.; Wang, S. X.; Zhao, B.; Chang, X.; Hao, J. M. Development of a unit-based industrial emission inventory in the Beijing-Tianjin-Hebei region and resulting improvement in air quality modeling. Atmos. Chem. Phys. 2019, 19 (6), $3447-3462$

(51) Rohrer, F.; Lu, K. D.; Hofzumahaus, A.; Bohn, B.; Brauers, T.; Chang, C. C.; Fuchs, H.; Haseler, R.; Holland, F.; Hu, M.; Kita, K.; Kondo, Y.; Li, X.; Lou, S. R.; Oebel, A.; Shao, M.; Zeng, L. M.; Zhu, T.; Zhang, Y. H.; Wahner, A. Maximum efficiency in the hydroxyl-radical-based self-cleansing of the troposphere. Nat. Geosci. 2014, 7 (8), 559-563. 
(52) Lu, K. D.; Rohrer, F.; Holland, F.; Fuchs, H.; Brauers, T.; Oebel, A.; Dlugi, R.; Hu, M.; Li, X.; Lou, S. R.; Shao, M.; Zhu, T.; Wahner, A.; Zhang, Y. H.; Hofzumahaus, A. Nighttime observation and chemistry of HOx in the Pearl River Delta and Beijing in summer 2006. Atmos. Chem. Phys. 2014, 14 (10), 4979-4999.

(53) Tan, Z.; Fuchs, H.; Lu, K.; Hofzumahaus, A.; Bohn, B.; Broch, S.; Dong, H.; Gomm, S.; Häseler, R.; He, L.; Holland, F.; Li, X.; Liu, Y.; Lu, S.; Rohrer, F.; Shao, M.; Wang, B.; Wang, M.; Wu, Y.; Zeng, L.; Zhang, Y.; Wahner, A.; Zhang, Y. Radical chemistry at a rural site (Wangdu) in the North China Plain: observation and model calculations of $\mathrm{OH}, \mathrm{HO}_{2}$ and $\mathrm{RO}_{2}$ radicals. Atmos. Chem. Phys. 2017, 17 (1), 663-690.

(54) Tan, Z. F.; Rohrer, F.; Lu, K. D.; Ma, X. F.; Bohn, B.; Broch, S.; Dong, H. B.; Fuchs, H.; Gkatzelis, G. I.; Hofzumahaus, A.; Holland, F.; Li, X.; Liu, Y.; Liu, Y. H.; Novelli, A.; Shao, M.; Wang, H. C.; Wu, Y. S.; Zeng, L. M.; Hu, M.; Kiendler-Scharr, A.; Wahner, A.; Zhang, Y. H. Wintertime photochemistry in Beijing: observations of ROx radical concentrations in the North China Plain during the BEST-ONE campaign. Atmos. Chem. Phys. 2018, 18 (16), 1239112411.

(55) Lu, K.; Fuchs, H.; Hofzumahaus, A.; Tan, Z.; Wang, H.; Zhang, L.; Schmitt, S. H.; Rohrer, F.; Bohn, B.; Broch, S.; Dong, H.; Gkatzelis, G. I.; Hohaus, T.; Holland, F.; Li, X.; Liu, Y.; Liu, Y.; Ma, X.; Novelli, A.; Schlag, P.; Shao, M.; Wu, Y.; Wu, Z.; Zeng, L.; Hu, M.; Kiendler-Scharr, A.; Wahner, A.; Zhang, Y. Fast Photochemistry in Wintertime Haze: Consequences for Pollution Mitigation Strategies. Environ. Sci. Technol. 2019, 53 (18), 10676-10684.

(56) Srivastava, R. K.; Miller, C. A.; Erickson, C.; Jambhekar, R. Emissions of sulfur trioxide from coal-fired power plants. J. Air Waste Manage. Assoc. 2004, 54 (6), 750-762.

(57) Yang, Z. D.; Zheng, C. H.; Zhang, X. F.; Zhou, H.; Silva, A. A.; Liu, C. Y.; Snyder, B.; Wang, Y.; Gao, X. Challenge of $\mathrm{SO}_{3}$ removal by wet electrostatic precipitator under simulated flue gas with high $\mathrm{SO}_{3}$ concentration. Fuel 2018, 217, 597-604.

(58) Guo, Y.; Yan, C.; Li, C.; Feng, Z.; Zhou, Y.; Lin, Z.; Dada, L.; Stolzenburg, D.; Yin, R.; Kontkanen, J.; Daellenbach, K. R.; Kangasluoma, J.; Yao, L.; Chu, B.; Wang, Y.; Cai, R.; Bianchi, F.; Liu, Y.; Kulmala, M. Atmos. Chem. Phys. Discuss. 2020, DOI: 10.5194/acp-2019-1111.

(59) Yao, L.; Wang, M.-Y.; Wang, X.-K.; Liu, Y.-J.; Chen, H.-F.; Zheng, J.; Nie, W.; Ding, A.-J.; Geng, F.-H.; Wang, D.-F.; Chen, J.M.; Worsnop, D. R.; Wang, L. Detection of atmospheric gaseous amines and amides by a high-resolution time-of-flight chemical ionization mass spectrometer with protonated ethanol reagent ions. Atmos. Chem. Phys. 2016, 16 (22), 14527-14543.

(60) Liu, L.; Zhong, J.; Vehkamaki, H.; Kurten, T.; Du, L.; Zhang, X.; Francisco, J. S.; Zeng, X. C. Unexpected quenching effect on new particle formation from the atmospheric reaction of methanol with $\mathrm{SO}_{3}$. Proc. Natl. Acad. Sci. U. S. A. 2019, 116 (50), 2496624971.

(61) Olin, M.; Kuuluvainen, H.; Aurela, M.; Kalliokoski, J.; Kuittinen, N.; Isotalo, M.; Timonen, H. J.; Niemi, J. V.; Rönkkö, T.; Dal Maso, M. Traffic-originated nanocluster emission exceeds $\mathrm{H}_{2} \mathrm{SO}_{4}$-driven photochemical new particle formation in an urban area. Atmos. Chem. Phys. 2020, 20 (1), 1-13.

(62) Ronkko, T.; Kuuluvainen, H.; Karjalainen, P.; Keskinen, J.; Hillamo, R.; Niemi, J. V.; Pirjola, L.; Timonen, H. J.; Saarikoski, S.; Saukko, E.; Jarvinen, A.; Silvennoinen, H.; Rostedt, A.; Olin, M.; YliOjanpera, J.; Nousiainen, P.; Kousa, A.; Dal Maso, M. Traffic is a major source of atmospheric nanocluster aerosol. Proc. Natl. Acad. Sci. U. S. A. 2017, 114 (29), 7549-7554. 